\title{
Plasma Somatostatin-like Immunoreactivity during the Interdigestive Period in the Dog
}

\author{
Isamu Aizawa, Zen Itoh, Virginia HaRris, and Roger H. Unger, \\ Veterans Administration Medical Center, Department of Internal Medicine of the \\ University of Texas Health Science Center, Dallas, Texas 75216; \\ Gastrointestinal Laboratories, Department of Surgery of The Gunma University \\ School of Medicine, Maebashi, Japan 371
}

A B S T R A C T To study possible physiologic relationships between somatostatin and the gastric interdigestive contractions (GIC), gastric motor activity, and plasma somatostatin-like immunoreactivity (SLI) concentration were determined simultaneously in four conscious dogs, each of which was studied on two separate occasions. Plasma SLI level was highest during the GIC period and lowest 60 and $80 \mathrm{~min}$ after the cessation of the GIC; the mean difference in plasma SLI was $41 \pm 6 \mathrm{pg} / \mathrm{ml}$. When synthetic motilin, a known stimulus of GIC, was infused at a physiologic rate during the period in which plasma SLI levels were low, SLI rose to approximately the same values observed during the contraction period and GIC similar to those that occur spontaneously were observed. When synthetic somatostatin, a known inhibitor of endogenous motilin release, was infused at a rate that raised the plasma SLI to approximately the levels observed during the contraction period $(0.1 \mu \mathrm{g} / \mathrm{kg}$ per $\mathrm{h})$, the appearance of the subsequent GIC was significantly delayed.

These results are consistent with a physiological role for somatostatin in the regulation of GIC in dogs and suggest an interrelationship between motilin and somatostatin.

\section{INTRODUCTION}

In the fasted state the human $(1,2)$ and canine (3-5) gastrointestinal tract exhibits a type of motor activity called the "interdigestive contractions" or "phase III" of the interdigestive myoelectric complex. The contractions are observed only in the conscious state and occur after a post-prandial interval the length of

Dr. Unger is a Senior Medical Investigator, Veterans Administration.

Received for publication 7 August 1980 and in revised form 4 March 1981 which depends upon the amount and nature of the food (6). They have a fixed duration and they recur at regular intervals $(3,4)$. Duodenal interdigestive contractions occur simultaneously with those of the stomach and migrate aborally along the small intestine to the terminal ileum $(3,5)$.

Somatostatin in pharmacological doses has been reported to inhibit the regular occurrence of the contraction in the stomach and upper intestine, but not in the lower intestine (7), but the physiological role of the somatostatin, if any, on the gastric interdigestive contractions has not been studied.

The purpose of the present study was to look for evidence of a physiologic relationship of somatostatin to the gastric interdigestive contraction (GIC). ${ }^{1}$

\section{METHODS}

10 mongrel dogs weighing $12-17 \mathrm{~kg}$ were used in the present study. Laparotomy was performed under pentobarbital anesthesia $(30 \mathrm{mg} / \mathrm{kg}$ ). A strain gauge transducer was sutured on the serosal surface of the gastric antrum, so as to record the circular muscle contractions. Two silicone catheters (OD = $2.2 \mathrm{~mm}$, Dow-Corning Corp., Midland, Mich.) were implanted. One was inserted through the external jugular vein to the superior vena cava and was used for blood sampling; the other was threaded through the femoral vein to the in ferior vena cava and was used for infusion (8). All surgical procedures were done under sterile conditions. The outer pieces of the lead wire and the tubing were shielded from scratching and chewing by a canvas protector. The precise details of construction and implantation of the transducer have been reported previously (9).

The lead wire of the transducer was plugged into the strain gauge coupler (MTT Co. Ltd., Takasaki, Japan). The output of the coupler was put into the main amplifier of a physiograph (Narco Bio-Systems, Inc., Houston, Tex.), which was generously loaned by Dr. C. T. Richardson and Dr. M. Feldman of the Gastroenterology Section, Veterans Administration

\footnotetext{
${ }^{1}$ Abbreviations used in this paper: GIC, gastric interdigestive contraction; SLI, somatostatin-like immunoreactivity.
} 
Medical Center. Motility of the stomach was traced by the pen-writing oscillograph of the physiograph with a paper speed of 1.5 or $0.15 \mathrm{~cm} / \mathrm{min}$.

Dogs were kept on a constant feeding schedule and were not used for more than two experiments per week.

A group of four dogs was used for experiments designed to examine the relationship between plasma levels of endogenous somatostatin and the GIC. Blood samples were obtained at 5-min intervals during at least two consecutive GIC on separate occasions.

Another group of five dogs was used to observe the effect of exogenous somatostatin on the intervals of GIC. Synthetic cyclic somatostatin (a gift from Dr. Jean Rivier, Salk Institute) was infused at a rate of $0.1 \mu \mathrm{g} / \mathrm{kg}$ per h. Either somatostatin or saline was infused beginning at $40 \mathrm{~min}$ after the GIC had stopped and continued until the next GIC was complete. Blood samples were not collected in these initial experiments that were intended only to identify a biologically effective dose of somatostatin. ${ }^{2}$ Time intervals from the end of the previous GIC to that of the next GIC were measured and were compared with those observed during the infusion of saline or somatostatin. Exogenous somatostatin infusion was discontinued when a GIC appeared. If no GIC appeared, somatostatin infusion was stopped after $240 \mathrm{~min}$, which is twice as long as the interval between GIC in the saline control study.

The third group of four dogs was used to examine the effect of exogenous motilin (a gift from Dr. H. L. Beyerman, University of Delft, The Netherlands) on the levels of endogenous somatostatin-like immunoreactivity (SLI) in the quiescent phase during the interdigestive period. An infusion of synthetic motilin was started $40 \mathrm{~min}$ after the cessation of the GIC and continued for $40 \mathrm{~min}$, and blood samples were taken at $-5,0,5,10,15,20,25,30,35,40,45,50,55$, and $60 \mathrm{~min}$. A few samples were also taken during the GIC.

Blood samples were collected in chilled tubes containing $6 \mathrm{mg}$ of EDTA and 500 kallikrein inhibition units Trasylol/ml of blood and centrifuged immediately at $2,500 \mathrm{cpm}$ for 30 min. Plasma was separated and stored in a freezer at $-20^{\circ} \mathrm{C}$ until the time of assay. Somatostatin was measured by a modification (10) of the methods of Kronheim et al. (11) and Arimura et al. (12). This procedure has been validated for use in unextracted dog plasma (13-15).

In eight experiments motor tracings were subdivided into 20 -min periods to facilitate the study of plasma SLI levels during the various phases of gastric activity. The period of interdigestive motor activity ("period 0 ") was defined as the 20-min period ending at the point of cessation of the gastric interdigestive contraction. Each 20 -min period immediately after period 0 was numbered from 1 to 6 . Additional periods were examined to determine the effect of initiation of GIC on plasma SLI levels. The 20 -min period immediately before the beginning of GIC was designated "period X" and the 20-min period immediately after the initiation of GIC "period Y". The mean SLI value in each time period was compared with every other period. An example of this system of subdivision appears in Fig. 1.

${ }^{2}$ After it had been established that $0.1 \mu \mathrm{g} / \mathrm{kg}$ per $\mathrm{h}$ was effective in delaying the onset of GIC, the concentration of plasma SLI produced by somatostatin at this rate of infusion was determined in three of the same group of dogs. Blood samples were obtained at $-15,-10,-5,0,5,10,15,20,25$, 30,35 , and 40 min and synthetic cyclic somatostatin was infused from 0 to $40 \mathrm{~min}$ starting at $40 \mathrm{~min}$ after the cessation of the GIC in two experiments in each of three dogs. A few samples were also obtained during the contraction period and compared to the SLI level during the infusion.
Gastric motility tracings were analyzed quantitatively as follows. Each contraction was rated as percentage of the maximum contraction of the interdigestive period for each day. After a period of quiescence, the interdigestive contraction was considered to have begun when motor activity having $>10 \%$ of the maximal contraction was observed.

In the motilin infusion study the motility index was calculated in two different ways for different purposes. To evaluate the biological potency of the synthetic motilin, 20-min periods were selected because the average spontaneous GIC lasts $20 \mathrm{~min}$. The sum of the amplitude of contractions during each period was calculated in two experiments in each of four dogs during an infusion of $0.1 \mu \mathrm{g} / \mathrm{kg}$ per h of motilin and in two experiments in each of three dogs of this group during an infusion of $0.2 \mu \mathrm{g} / \mathrm{kg}$ per $\mathrm{h}$. The value obtained from each experiment was regarded as the motility index during the period of maximum contraction and a comparison of natural GIC and motilin-induced GIC was made.

In order to examine closely the relationship between gastric contraction and the rapidly changing peripheral SLI levels, a motility index was calculated on the basis of 5-min intervals from the start to the end of the infusion. The sum of the amplitude of every contraction in each period was calculated and was divided by the amplitude of the maximum contraction of the previous spontaneous GIC so as to standardize the motility index in different dogs. The relationship of the motility index to the mean increase of peripheral SLI level was evaluated in the eight experiments in which motilin was infused at the low rate.

The data was treated by analysis of variance (16) and by the Newman-Keuls procedure for multiple comparisons (17). Data in Fig. 6, comparing a preinfusion value to each other value, was analyzed by Dunnett's test (17). The level of 0.05 was considered significant for all tests.

\section{RESULTS}

Duration of gastric motor activity and quiescent intervals during blood sampling. During blood sampling at 5-min intervals the mean quiescent period $( \pm \mathrm{SEM})$ was $102 \pm 20 \mathrm{~min}(n=8)$ and the mean duration of the subsequent GIC was $75 \pm 12 \min (n=8)$. The mean interval between two consecutive contractions was $176 \pm 15 \min (n=8)$.

Relationship of plasma somatostatin levels to the interdigestive motor activity. In Table I the plasma SLI concentrations in period 0 of the first episode of GIC were compared to those in periods 1 through 6 . Mean SLI levels in periods 2, 3, 4, and 5 were significantly lower than those in period $0(P<0.05)$; but periods 1 and 6 did not differ significantly. Plasma SLI concentration reached its lowest value of $114 \pm 9 \mathrm{pg} / \mathrm{ml}$ in period 4 .

In four of the eight experiments the gastric motility of the next episode of GIC began in period 5. To determine if the beginning of the second episode of GIC is associated with a change in SLI levels, the mean value in the 20 -min period immediately before the onset of the second GIC (period X) and that in the first 20 min of the second GIC (period Y) were compared. The mean SLI value in period $X(118 \pm 12$ $\mathrm{pg} / \mathrm{ml}$ ) was significantly lower than that of period $\mathrm{Y}$ 


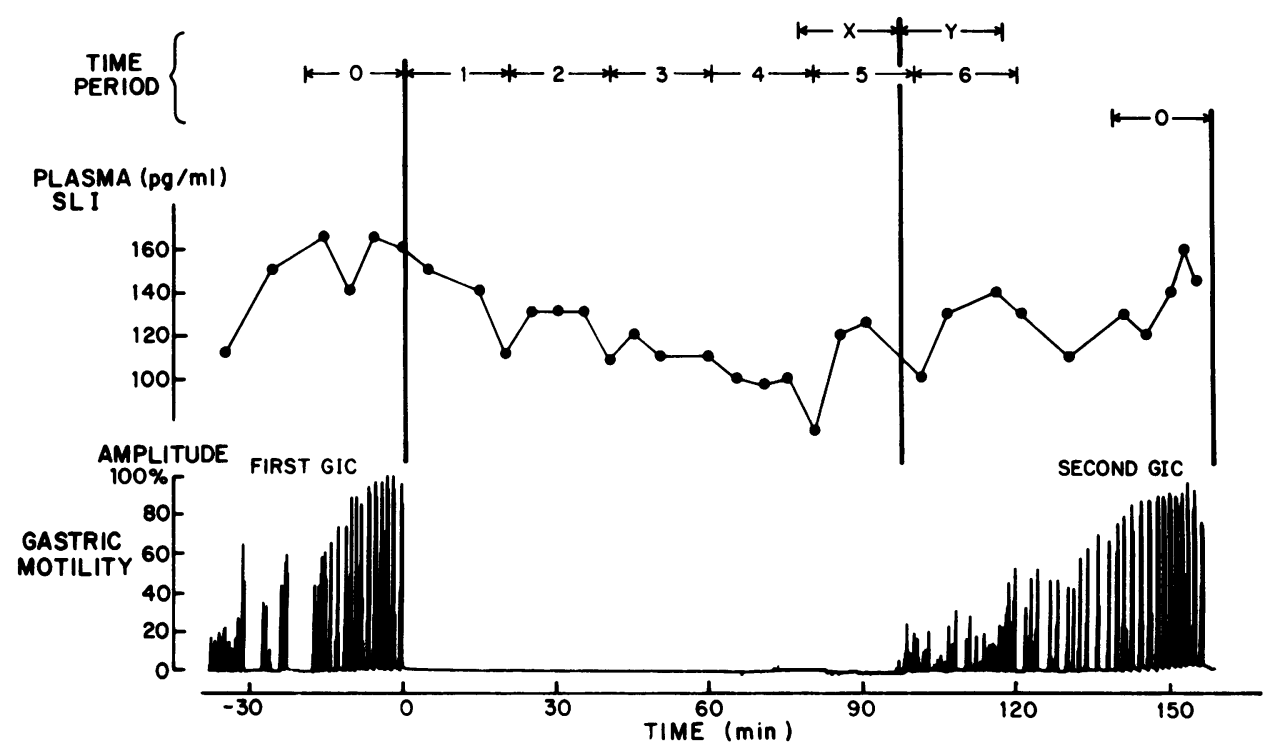

FIGURE 1 The relationship between gastric movement and the plasma SLI levels in one of eight experiments. At the top of this figure is shown an example of time divisions based on the motility tracings at the bottom, for the comparison of the concentration of plasma SLI in eight experiments. Vertical axis for the gastric movement represents the amplitude of contraction and horizontal axis represents time-course.

$(133 \pm 16 \mathrm{pg} / \mathrm{ml} ; P<0.05)$, the subsequent period 0 $(146 \pm 12 \mathrm{pg} / \mathrm{ml} ; P<0.05)$ and the previous period 0 $(155 \pm 14 \mathrm{pg} / \mathrm{ml} ; P<0.05$ ) (Table II).

To determine whether there was a relationship between the SLI levels and the amplitude of antral contractions, the amplitude of the largest contraction during 2.5 min before and after each blood sampling point was quantitated as percentage of the highest contraction in the entire experiment. The SLI values associated with contractions of large amplitude $(80-$ $100 \%$ ) were compared with those associated with contractions of small amplitude (10-60\%). The mean SLI value during contractions of large amplitude, $151 \pm 13$ $\mathrm{pg} / \mathrm{ml}$, was significantly higher than that associated with contractions of small amplitude, $136 \pm 10 \mathrm{pg} / \mathrm{ml}$. They were also significantly higher than those in period $\mathrm{X}(118 \pm 12 \mathrm{pg} / \mathrm{ml})$ (Table III).

The effect of exogenous somatostatin on the intervals between gastric interdigestive contractions. Somatostatin infusion significantly delayed the occurrence of the next GIC compared with saline infusion in all five dogs studied. During saline control infusion the intervals between contractions averaged $137 \pm 12 \mathrm{~min}$ in the five dogs. During somatostatin infusion at a rate of $0.1 \mu \mathrm{g} / \mathrm{kg}$ per $\mathrm{h}$ it increased to $215 \pm 7 \mathrm{~min}(P<0.01$ for each dog), as shown in Table IV. This rate of somatostatin infusion raised the plasma SLI level between 5 to $25 \mathrm{~min}$ by only $20-15 \mathrm{pg} / \mathrm{ml}$ (Fig. 2), and the values did not differ significantly from the peak SLI value of the previous GIC.
The effect of synthetic motilin infusion on the gastric motility. As reported previously (18), a characteristic GIC appeared within 5 min after the start of the infusion of motilin at a rate of 0.1 and $0.2 \mu \mathrm{g} / \mathrm{kg}$ per h, but not during the saline control infusion. During the low rate infusion of motilin, the motility index during the period of maximum contraction was significantly less than that of spontaneously occurring GIC. But at the high infusion rate the motility index was significantly greater than that of natural GIC, as shown in Table $\mathrm{V}$.

The effect of motilin infusion on plasma SLI level. The infusion of motilin at $0.1 \mu \mathrm{g} / \mathrm{kg}$ per $\mathrm{h}$ during the quiescent period was associated with an increase of

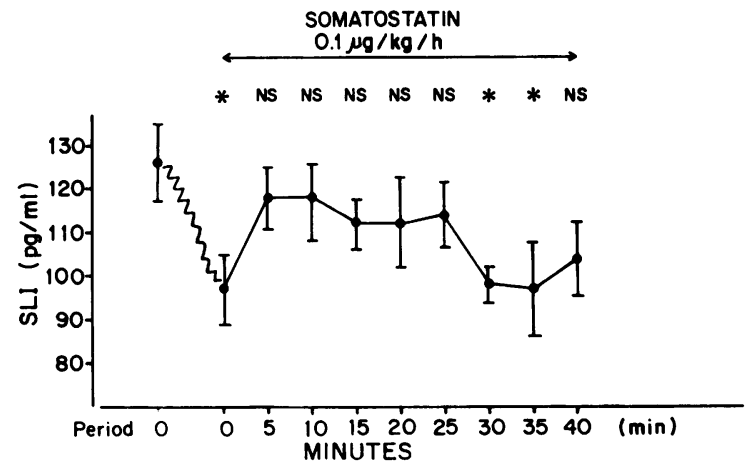

FIGURE 2 The effect of somatostatin infusion on peripheral plasma SLI levels $(n=6) .{ }^{*}$, significant difference of $P<0.05$ from period 0 . 
TABLE I

Mean Plasma SLI Values (Picograms per Milliliter) during the Interdigestive Period

\begin{tabular}{|c|c|c|c|c|c|c|c|}
\hline \multirow[b]{2}{*}{ Period... } & \multicolumn{7}{|c|}{ Plasma SLI value $(\mathrm{pg} / \mathrm{ml})$} \\
\hline & 0 & 1 & 2 & 3 & 4 & 5 & 6 \\
\hline \multicolumn{8}{|l|}{ Dog } \\
\hline \multirow[t]{4}{*}{1} & $185 \pm 9$ & $163 \pm 13$ & $143 \pm 11$ & $141 \pm 8$ & $136 \pm 8$ & $140 \pm 6$ & $188 \pm 20$ \\
\hline & 4 & 4 & 4 & 4 & 4 & 4 & 4 \\
\hline & $159 \pm 6$ & $145 \pm 14$ & $125 \pm 6$ & $113 \pm 3$ & $95 \pm 4$ & $148 \pm 24$ & $125 \pm 9$ \\
\hline & 4 & 4 & 4 & 4 & 4 & 3 & 4 \\
\hline \multirow[t]{4}{*}{2} & $177 \pm 12$ & $163 \pm 6$ & $133 \pm 8$ & $144 \pm 4$ & $121 \pm 8$ & $156 \pm 12$ & $180 \pm 4$ \\
\hline & 3 & 4 & 4 & 4 & 4 & 4 & 4 \\
\hline & $121 \pm 4$ & $113 \pm 6$ & $98 \pm 3$ & $100 \pm 2$ & $100 \pm 4$ & $115 \pm 8$ & $121 \pm 4$ \\
\hline & 4 & 4 & 4 & 4 & 4 & 4 & 3 \\
\hline \multirow[t]{4}{*}{3} & $150 \pm 10$ & $125 \pm 6$ & $98 \pm 9$ & $112 \pm 11$ & $114 \pm 14$ & $121 \pm 11$ & $121 \pm 10$ \\
\hline & 4 & 4 & 2 & 4 & 4 & 4 & 4 \\
\hline & $178 \pm 3$ & $168 \pm 12$ & $152 \pm 7$ & $141 \pm 10$ & $127 \pm 6$ & $133 \pm 6$ & $168 \pm 24$ \\
\hline & 4 & 5 & 4 & 4 & 4 & 5 & 4 \\
\hline \multirow[t]{4}{*}{4} & $78 \pm$ & $77 \pm 3$ & $74 \pm 8$ & $60 \pm 4$ & $68 \pm 8$ & $75 \pm 9$ & $80 \pm 2$ \\
\hline & 2 & 3 & 3 & 5 & 3 & 3 & 4 \\
\hline & $194 \pm 11$ & $189 \pm 10$ & $171 \pm 10$ & $160 \pm 3$ & $150 \pm 5$ & $198 \pm 23$ & $193 \pm 28$ \\
\hline & 4 & 4 & 4 & 4 & 2 & 2 & 2 \\
\hline Mean & $155 \pm 14^{*}$ & $142 \pm 12^{*}+$ & $124 \pm 11 \S$ & $121 \pm 11 \S$ & $114 \pm 9 \S$ & $136 \pm 13 \ddagger$ & $147 \pm 14^{*} \cdot t$ \\
\hline
\end{tabular}

Period 0 was defined as 20 -min period ending at the point of cessation of the first GIC, and the following 20-min period was numbered from 1 to 6 . Values presented are mean $\pm S E M$ in each period in two experiments in each of four dogs. Figures under each value indicate the number of samples in each period. A different superscript indicates that values differ significantly from one another $(P<0.05)$; i.e., if there are two values with the same letter, they are not different.

plasma SLI to a peak of $122 \pm 6 \mathrm{pg} / \mathrm{ml}$, a value that was significantly higher $(P<0.05)$ than the preinfusion value. With the $0.2 \mu \mathrm{g} / \mathrm{kg}$ per $\mathrm{h}$ motilin infusion, the mean SLI level rose to a peak of $159 \pm 38 \mathrm{pg} / \mathrm{ml}$; however, this was not significantly above the preinfusion value because of greater variation (Fig. 3).

The mean SLI value in the period of maximum contraction during both doses of motilin did not differ statistically from those observed during natural GIC (Table VI). However, mean SLI levels from 15 to 30 min after the start of saline infusion (this was the period when the mean motility index was at a peak level in eight experiments with the low rate infusion of motilin) were significantly lower than during the maximum contraction period before the saline infusion $(P<0.005)$. The SLI levels during saline infusion period did not differ significantly from those during motilin infusions.

To determine the relationship between the increase of gastric motility and the change of peripheral SLI levels, the mean motility index and the mean increase of SLI from the preinfusion value were com- pared in eight experiments in which motilin was infused at a rate of $0.1 \mu \mathrm{g} / \mathrm{kg}$ per $\mathrm{h}$ in four dogs. The peak SLI value was observed at $30 \mathrm{~min}$ after the start of infusion, and the peak motility index occurred at 15-20 min after the start of the infusion, but this difference in time was not statistically significant (Fig. 4). There was no correlation between the mean motility index and the mean increase in SLI.

\section{DISCUSSION}

This study is the first attempt to determine if a relationship exists between the plasma somatostatin level and spontaneous and motilin-induced GIC. Plasma somatostatin levels were found to rise in close relation to spontaneous GIC, and to decline during the ensuing quiescent period. The mean increase in peripheral SLI was $\sim 40 \mathrm{pg} / \mathrm{ml}$, which is about half the rise observed during a protein meal (15).

Various phenomena have been reported to accompany the GIC. These include increased levels of plasma motilin (19-22) and pancreatic polypeptide (22), and 
TABLE II

Comparison of Plasma SLI Levels (Picograms per Milliliter) among Period 0 of the First GI, Period X, Period Y, and Period 0 of the Second GIC

\begin{tabular}{|c|c|c|c|c|}
\hline \multirow[b]{2}{*}{ Dog } & \multicolumn{4}{|c|}{ Plasma SLI value (pg/ml) } \\
\hline & $\begin{array}{l}\text { Period } 0 \text { of } \\
\text { 1st GIC }\end{array}$ & Period X & Period Y & $\begin{array}{l}\text { Period } 0 \text { of } \\
\text { 2nd GIC }\end{array}$ \\
\hline \multirow[t]{4}{*}{1} & $185 \pm 9$ & $152 \pm 4$ & $160 \pm 9$ & $192 \pm 16$ \\
\hline & 4 & 3 & 4 & 4 \\
\hline & $159 \pm 6$ & $112 \pm 14$ & $123 \pm 12$ & $139 \pm 7$ \\
\hline & 4 & 3 & 3 & 5 \\
\hline \multirow[t]{4}{*}{2} & $177 \pm 12$ & $121 \pm 5$ & $165 \pm 7$ & $172 \pm 8$ \\
\hline & 3 & 4 & 4 & 4 \\
\hline & $121 \pm 4$ & $98 \pm 1$ & $111 \pm 7$ & $147 \pm 5$ \\
\hline & 4 & 4 & 3 & 4 \\
\hline \multirow[t]{4}{*}{3} & $150 \pm 10$ & $102 \pm 8$ & $100 \pm 2$ & $123 \pm 12$ \\
\hline & 2 & 3 & 5 & 3 \\
\hline & $178 \pm 3$ & $124 \pm 3$ & $125 \pm 5$ & $153 \pm 3$ \\
\hline & 2 & 3 & 5 & 3 \\
\hline \multirow[t]{4}{*}{4} & $78 \pm$ & $63 \pm 5$ & $70 \pm 7$ & $80 \pm 5$ \\
\hline & 2 & 4 & 4 & 4 \\
\hline & $193 \pm 11$ & $170 \pm 5$ & $215 \pm 5$ & $159 \pm 12$ \\
\hline & 4 & 2 & 2 & 2 \\
\hline Mean & $155 \pm 14^{*}$ & $118 \pm 12 \ddagger$ & $133 \pm 16 \oint$ & $146 \pm 12^{*} \S$ \\
\hline
\end{tabular}

Period 0 was defined as the same as in Table $I$ in both first and second GIC. Period X was defined as 20 -min period ending at the point of initiation of the second GIC and the following $20 \mathrm{~min}$ was named as period $\mathrm{Y}$. Values presented are mean $\pm S E M$ in two experiments in each of four dogs. Figures under each value indicate the number of samples in each period. Mean values with a different superscript differ significantly from one another $(P<0.05)$.

increased secretion of gastric acid (23), pancreatic enzymes and bile $(22,24)$. There is a simultaneous occurrence of interdigestive duodenal contractions that migrate aborally along the whole intestine as a strong band $(3,5)$, increasing the intestinal flow rate $(25)$. Therefore the interdigestive phase is a period of change in endocrine, exocrine, and muscular activities of the digestive system. Plasma SLI can be added to the list of parameters that change during the interdigestive period. It should be noted that the minimal level of somatostatin was present only between 20 and $80 \mathrm{~min}$ after a GIC. This fact may account for variations in base-line values of plasma peripheral SLI observed in the fasting state $(15,26)$.

Motilin has been suspected as a possible initiator of these cyclic phenomena in the interdigestive period $(18,20)$. Plasma motilin levels are the highest during GIC (20) or in phase III of the duodenal interdiges-
TABLE III

Comparison of the Mean SLI Values among the Period of Small Amplitude Contractions and Large Amplitude Contractions and the Period X

\begin{tabular}{|c|c|c|c|}
\hline \multirow[b]{2}{*}{ Dog } & \multicolumn{3}{|c|}{ Plasma SLI value $(\mathrm{pg} / \mathrm{ml})$} \\
\hline & Period X & $\begin{array}{c}\text { Small } \\
\text { amplitude }\end{array}$ & $\begin{array}{c}\text { Large } \\
\text { amplitude }\end{array}$ \\
\hline \multirow[t]{4}{*}{1} & $152 \pm 4$ & $151 \pm 7$ & $190 \pm 7$ \\
\hline & 3 & 4 & 9 \\
\hline & $112 \pm 14$ & $132 \pm 7$ & $146 \pm 6$ \\
\hline & 3 & 13 & 8 \\
\hline \multirow[t]{4}{*}{2} & $121 \pm 5$ & $148 \pm 13$ & $173 \pm 6$ \\
\hline & 4 & 2 & 10 \\
\hline & $98 \pm 1$ & $125 \pm 6$ & $137 \pm 4$ \\
\hline & 4 & 6 & 13 \\
\hline \multirow[t]{4}{*}{3} & $102 \pm 8$ & $129 \pm 9$ & $125 \pm 6$ \\
\hline & 3 & 7 & 12 \\
\hline & $124 \pm 3$ & $156 \pm 5$ & $179 \pm 7$ \\
\hline & 3 & 23 & 8 \\
\hline \multirow[t]{4}{*}{4} & $63 \pm 5$ & $75 \pm 3$ & $80 \pm 3$ \\
\hline & 4 & 12 & 12 \\
\hline & $170 \pm 5$ & $174 \pm 8$ & $181 \pm 11$ \\
\hline & 2 & 15 & 7 \\
\hline Mean \pm SEM & $118 \pm 12^{*}$ & $136 \pm 10 \ddagger$ & $151 \pm 13 \S$ \\
\hline
\end{tabular}

Period $\mathrm{X}$ was defined as 20 -min period ending at the point of initiation of the second GIC. Values presented are mean \pm SEM in two experiments in each of four dogs. Figures under each value indicate the number of samples. Mean value with a different superscript differ significantly from one another $(P<0.05)$.

tive myoelectric complex $(19,22)$. Exogenous motilin in a physiological dose induces a motor pattern re-

TABLE IV

The Effect of Synthetic Somatostatin on the Intervals of GIC

\begin{tabular}{cccc}
\hline & \multicolumn{2}{c}{ Intervals (min) } & \\
\cline { 2 - 3 } Dog & Saline & Somatostatin & $\begin{array}{c}P \text { value saline vs. } \\
\text { somatostatin }\end{array}$ \\
\hline 1 & $151 \pm 6$ & $236 \pm 12$ & $<0.01$ \\
2 & $99 \pm 2$ & $198 \pm 16$ & $<0.01$ \\
3 & $129 \pm 14$ & $207 \pm 6$ & $<0.01$ \\
4 & $172 \pm 6$ & $229 \pm 8$ & $<0.01$ \\
5 & $132 \pm 13$ & $207 \pm 14$ & $<0.01$ \\
Mean \pm SEM & $137 \pm 12$ & $215 \pm 7$ & \\
\hline
\end{tabular}

The values presented are the mean \pm SEM of five experiments in each of five dogs. Both somatostatin and saline were infused from $40 \mathrm{~min}$ after the first GIC until the end of the next GIC. Intervals were defined as the time period between the end point of the first GIC to the second GIC, or to the end point of somatostatin infusion. 
TABLE V

Motility Index (Millimeter) during Natural and Motilin-induced GIC in Two Separate Experiments in Four Dogs

\begin{tabular}{|c|c|c|c|c|c|}
\hline \multirow[b]{3}{*}{ Dog } & \multirow[b]{3}{*}{ Expt. } & \multicolumn{4}{|c|}{ Motility index (mm) } \\
\hline & & \multicolumn{2}{|c|}{ Low dose $(0.1 \mu \mathrm{g} / \mathrm{kg} / \mathrm{h})$} & \multicolumn{2}{|c|}{ High dose $(0.2 \mu \mathrm{g} / \mathrm{kg} / \mathrm{h})$} \\
\hline & & $\begin{array}{l}\text { Natural } \\
\text { GIC }\end{array}$ & $\begin{array}{l}\text { Motilin-induced } \\
\text { GIC }\end{array}$ & $\begin{array}{l}\text { Natural } \\
\text { GIC }\end{array}$ & $\begin{array}{l}\text { Motilin-induced } \\
\text { GIC }\end{array}$ \\
\hline \multirow[t]{2}{*}{5} & 1 & 1,198 & 622 & 950 & 1,562 \\
\hline & 2 & 1,059 & 907 & 1,309 & 1,926 \\
\hline \multirow[t]{2}{*}{6} & 1 & 949 & 1,093 & 791 & 981 \\
\hline & 2 & 1,249 & 1,004 & 1,049 & 1,336 \\
\hline \multirow[t]{2}{*}{7} & 1 & 873 & 582 & 1,209 & 1,138 \\
\hline & 2 & 1,354 & 515 & 742 & 984 \\
\hline \multirow[t]{2}{*}{8} & 1 & 868 & 641 & & \\
\hline & 2 & 1,177 & 760 & & \\
\hline Mean \pm SEM & & $1,091 \pm 65$ & $766 \pm 75$ & $1,008 \pm 92$ & $1,321 \pm 229$ \\
\hline$P$ value & & L & $.05 ـ$ & L $<$ & $.05 ـ$ \\
\hline
\end{tabular}

The values presented are sum of the amplitude of the contractions during the $20-$ min period that yielded the largest sum for each GIC. Motilin infusion was started at 40 min after the preceding natural GIC.

sembling spontaneous interdigestive contractions (18, $19,27)$, a faict confirmed in the present study. The lower dose of synthetic motilin $(0.1 \mu \mathrm{g} / \mathrm{kg}$ per h) used in the present study seemed to be in a physiologic range in that the GIC produced by its continuous infusion was quantitatively similar to naturally occurring GIC. Moreover, this low dose of motilin increased

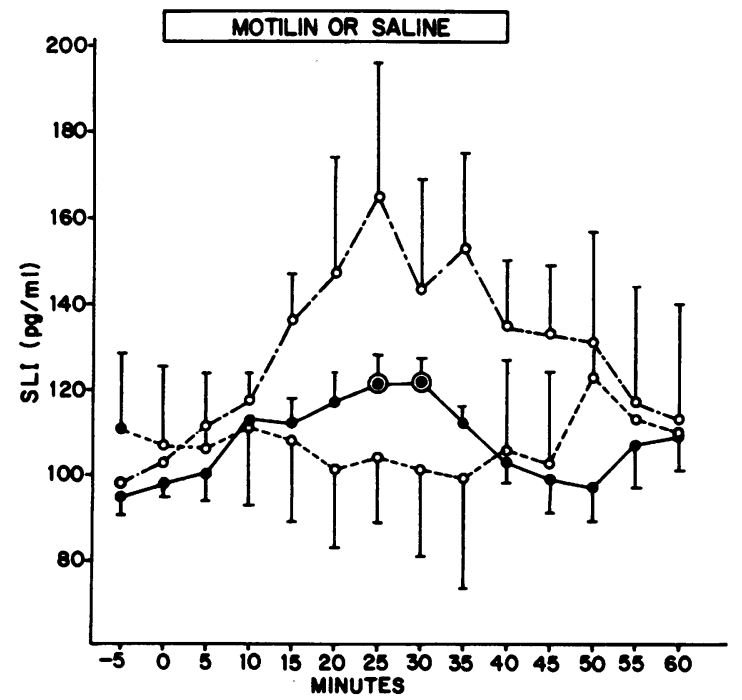

Figure 3 The effect of exogenous motilin or saline on the peripheral level of SLI. $\odot$, significant difference of $P<0.05 \mathrm{vs.}$ 0 value. $\bigcirc-\bigcirc, 0.2 \mu \mathrm{g} / \mathrm{kg}$ per h $(n=6) ; 0-0,0.1 \mu \mathrm{g} / \mathrm{kg}$ per h $(n=8)$; $\bigcirc---O$, saline $(n=4)$. the peripheral SLI levels to those that occur during a spontaneous GIC. This suggests that the rise of somatostatin during natural GIC is somehow related to the rise of endogenous motilin.

Exogenous somatostatin, infused in doses that produced plasma SLI levels that did not exceed the peak values of endogenous SLI observed during the interdigestive phase, delayed significantly the intervals be-

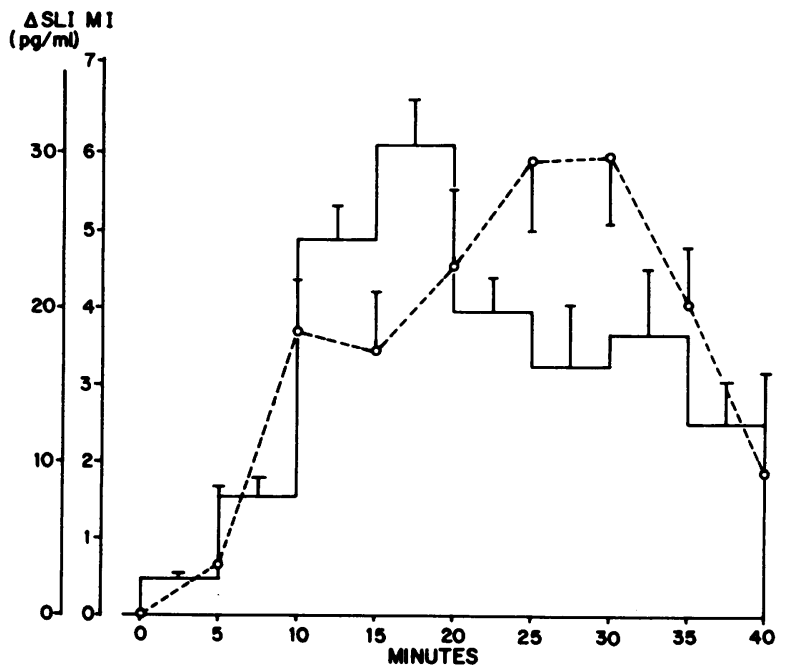

FIGURE 4 Motility index (MI) and SLI during infusion of 0.1 $\mu \mathrm{g} / \mathrm{kg}$ per $\mathrm{h}$ of motilin. Broken line represents mean $\pm \mathrm{SEM}$ of SLI and histogram indicates the mean \pm SEM of motility index in two experiments in each of four dogs. 
TABLE VI

Mean Plasma SLI Value (Picograms per Milliliter) during Natural and Motilin-induced GIC

\begin{tabular}{ccccccc}
\hline & \multicolumn{7}{c}{ Plasma SLI value (pg/ml) } \\
\cline { 2 - 7 } Dog & $\begin{array}{c}\text { Natural } \\
\text { GIC }\end{array}$ & Saline & Natural & $\begin{array}{c}\text { Motilin } 0.1 \\
\mu \text { gIC }\end{array}$ & $\begin{array}{c}\text { Natural } \\
\text { GIC }\end{array}$ & $\begin{array}{c}\text { Motilin } 0.2 \\
\mu \text { g/kg per h }\end{array}$ \\
\hline 5 & $106 \pm 5$ & $69 \pm 5$ & $132 \pm 11$ & $121 \pm 3$ & $114 \pm 7$ & $110 \pm 7$ \\
& 5 & 4 & 3 & 4 & 3 & 4
\end{tabular}

Values presented are mean \pm SEM in 20 -min period that was selected for each GIC to yield the largest sum of the amplitude of the contraction except during saline infusion. In the saline infusion study they are the mean SLI value from 15 to $30 \mathrm{~min}$ after the start of saline infusion. Figures under each value indicate the number of samples in each period.

tween the two consecutive GIC. This suggests that somatostatin may function as an inhibitor of the cyclic occurrence of the GIC in the interdigestive period in dog. Pharmacological doses of somatostatin inhibit both natural and motilin-induced GIC (7) and also suppress the endogenous release of motilin in the interdigestive period (28) and after meals (29). A small rise of somatostatin during the quiescent period could delay the next GIC by inhibiting release of motilin, whereas a reduction in plasma SLI during the quiescent period may be important for recurrence of the GIC. A positive-negative feedback relationship between motilin and somatostatin can be envisioned as regulating the frequency, duration and amplitude of GIC. Whether these findings in dogs are applicable to other species remains to be determined.

\section{ACKNOWLEDGMENTS}

The authors wish to thank the following persons for their expert technical assistance; Lorretta Clendenen, John Diffie, Helen Gibson, Woody Hilton, Mary Lintner, Kay McCorkle, Lovie Peace, Dale Prince, Danny Sandlin, and Cathy Smith.
Dr. W. A. Woodward has contributed invaluable aid in the statistical evaluation of the data. The authors express their thanks to Susan Kennedy and Jessie Reese for secretarial assistance.

This work was supported by Veterans Administration Institutional Research Support grant 549-8000-01; National Institutes of Health grant AM-02700-16 and contract NOI-AM62219; CIBA-Geigy Corp., Summit, N. J.; Eli Lilly \& Co., Indianapolis, Ind.; The Salk Institute-Texas Research Foundation, Houston, Texas.

\section{REFERENCES}

1. Vantrappen, G., J. Janssens, J. Hellemans, and Y. Ghoos. 1977. The interdigestive motor complex of normal subjects and patients with bacterial overgrowth of the small intestine. J. Clin. Invest. 59: 1158-1166.

2. Fleckenstein, P., and A. Oigaard. 1978. Electrical spike activity in the human small intestine: a multiple electrode study of fasting diurnal variations. Am. J. Dig. Dis. 23: $776-780$.

3. Code, C. F., and J. A. Marlett. 1975. The interdigestive myo-electric complex of the stomach and small bowel of dogs. J. Physiol. (Lond.). 246: 289-309.

4. Itoh, Z., I. Aizawa, S. Takeushi, and R. Takayanagi. 
1977. Diurnal changes in gastric motor activity in conscious dogs. Am. J. Dig. Dis. 22: 117-124.

5. Itoh, Z., S. Takeushi, I. Aizawa, and R. Takayanagi. 1978. Characteristic motor activity of the gastrointestinal tract in fasted conscious dogs measured by implanted force transducers. Am. J. Dig. Dis. 23: 229-238.

6. De Wever, I., C. Eckhout, G. Vantrappen, and J. Hellemans. 1978. Disruptive effect of test meals on interdigestive motor complex in dogs. Am. J. Physiol. 235: E661665.

7. Ormsbee, H. S., S. T. Koehler, and G. L. Telford. 1978. Somatostatin inhibits motilin-induced interdigestive contractile activity in the dog. Am. J. Dig. Dis 23: 781-788.

8. Itoh, Z., N. Carlton, H. W. Lucien, and A. V. Schally. 1969. Long-term plastic tubing implantation into the external jugular vein for injection or infusion in the dog. Surgery. 66: 768-770.

9. Itoh, Z., R. Honda, S. Takeushi, I. Aizawa, and R. Takayanagi. 1977. An extraluminal force transducer for recording contractile activity of the gastrointestinal smooth muscle in the conscious dogs: its construction and implication. Gastroenterol. Jpn. 12: 275-283.

10. Harris, V., J. M. Conlon, C. B. Srikant, K. McCorkle, V. Schusdziarra, E. Ipp, and R. H. Unger. 1978. Measurements of somatostatin-like immunoreactivity in plasma. Clin. Chim. Acta. 87: 275-283.

11. Kronheim, S., M. Berelowitz, and B. L. Pimstone. 1976. A radiommunoassy for growth hormone release inhibiting hormone: method and quantitative tissue distribution. Clin. Endocrinol. 5: 619-630.

12. Arimura, A., H. Sato, D. H. Coy, and A. V. Schally. 1975. Radioimunoassay for GH-release inhibiting hormone. Proc. Soc. Exp. Biol. Med. 148: 784-789.

13. Schusdziarra, V., V. Harris, J. M. Conlon, A. Arimura, and R. H. Unger. 1978. Pancreatic and gastric somatostatin release in response to intragastric and intraduodenal nutrients and $\mathrm{HCl}$ in the dog.J. Clin. Invest. 62: 509-518.

14. Conlon, J. M., C. B. Srikant, E. Ipp, V. Schusdziarra, W. Vale, and R. H. Unger. 1978. Properties of endogenous somatostatin-like immunoreactivity and synthetic somatostatin in dog plasma. J. Clin. Invest. 62: 1187-1193.

15. Schusdziarra, V., D. Rouiller, V. Harris, J. M. Conlon, and R. H. Unger. 1978. The response of plasma somatostatin-like immunoreactivity to nutrients in normal and alloxan diabetic dogs. Endocrinology. 102: 22642273.

16. Winer, B. J. 1971. Statistical principles in experimental design. 2nd edition. McGraw Hill, Inc., New York.

17. Zar, J. H. 1974. Biostatistical Analysis. Prentice-Hall, Inc., Englewood, Cliffs, N. J.

18. Itoh, Z., S. Takeuchi, I. Aizawa, and R. Takayanagi. 1977.
Effect of synthetic motilin on gastric motor activity in conscious dogs. Am. J. Dig. Dis. 22: 813-819.

19. Lee, K. Y., W. Y. Chey, H. Tai, and H. Yajima. 1978. Radioimmunoassay of motilin: validation and studies on the relationship between plasma motilin and interdigestive myoelectric activity of the duodenum of dog. Am. J. Dig. Dis. 23: 789-795.

20. Itoh, Z., S. Takeuchi, I. Aizawa, K. Mori, T. Taminato, Y. Seino, H. Imura, and N. Yanaihara. 1978. Changes in plasma motilin concentration and gastrointestinal contractile activity in conscious dog. Am. J. Dig. Dis. 23: 929-935.

21. Vantrappen, G., J. Janssens, T. L. Peeters, S. R. Bloom, N. D. Christofides, and J. Hellemans. 1979. Motilin and the interdigestive migrating motor complex in man. Dig. Dis. Sci. 24: 497-500.

22. Keane, F. B., E. P. DiMango, R. R. Dozois, and V. L. M. Go. 1980. Relationships among canine interdigestive exocrine pancreatic and biliary flow, duodenal motor activity plasma pancreatic polypeptide, and motilin. Gastroenterology. 78: 310-316.

23. Steinbach, J. H., J. C. Hines, and C. F. Code. 1979. Gastric acid secretion during the interdigestive myoelectric complex. 63rd Annual Meeting of the American Physiological Society, April 6-10.

24. DiMagno, E. P., J. C. Hendricks, V. L. W. Go, and R. R. Dozois. 1979. Relationships among canine fasting pancreatic and biliary secretions, pancreatic duct pressure, and duodenal phase III motor activity-Boldyreff revisited. Dig. Dis. Sci. 24: 689-693.

25. Sarr, M. G., and K. A. Kelly. 1979. Jejunal transit of liquids and solids during jejunal interdigestive and digestive motor activity. Seventh International Symposium on Gastrointestinal Motility, Sept. 11-14.

26. Wasada, T., B. Howard, R. E. Dobbs, and R. H. Unger. 1980. Evidence for a role of FFA in the regulation of somatostatin secretion in normal and alloxan diabetic dogs. J. Clin. Invest. 66: 511-516.

27. Itoh, Z., R. Honda, K. Hiwatashi, S. Takeuchi, I. Aizawa, R. Takayanagi, and E. F. Couch. 1976. Motilin-induced mechanical activity in the canine alimentary tract. Scand. J. Gastroenterol.11(Suppl. 39): 93-110.

28. Poitras, P., J. Steinbach, G. VanDeventer, J. H. Walsh, and C. F. Code. 1979. Effect of somatostatin on interdigestive myoelectric complexes and motilin blood levels. Annual Meeting of American Gastroenterological Association, May 21-23.

29. Bloom, S. R., D. N. Ralphs, G. M. Besser, R. Hall, D. H. Coy, A. J. Kastin, and A. V. Schally. 1975. Effect of somatostatin on motilin levels and gastric emptying. Gut. 16: 834 . 